\title{
The Third International Workshop "Constructive Methods for Non-Linear Boundary Value Problems"
}

\author{
Miklós Rontó
}




\title{
THE THIRD INTERNATIONAL WORKSHOP “CONSTRUCTIVE METHODS FOR NON-LINEAR BOUNDARY VALUE PROBLEMS”
}

\author{
MIKLÓS RONTÓ
}

[Received: June 20, 2006]

In the period from 7th to 10th June, 2006, the Third International Workshop

“CONSTRuCtive Methods for Non-Linear Boundary Value

\section{Problems"}

took place in Sárospatak, Hungary. The workshop had been organised by the Institute of Mathematics of the University of Miskolc in cooperation with the Regional Committee of the Hungarian Academy of Sciences in Miskolc and the Comenius Teacher Training College of the University of Miskolc.

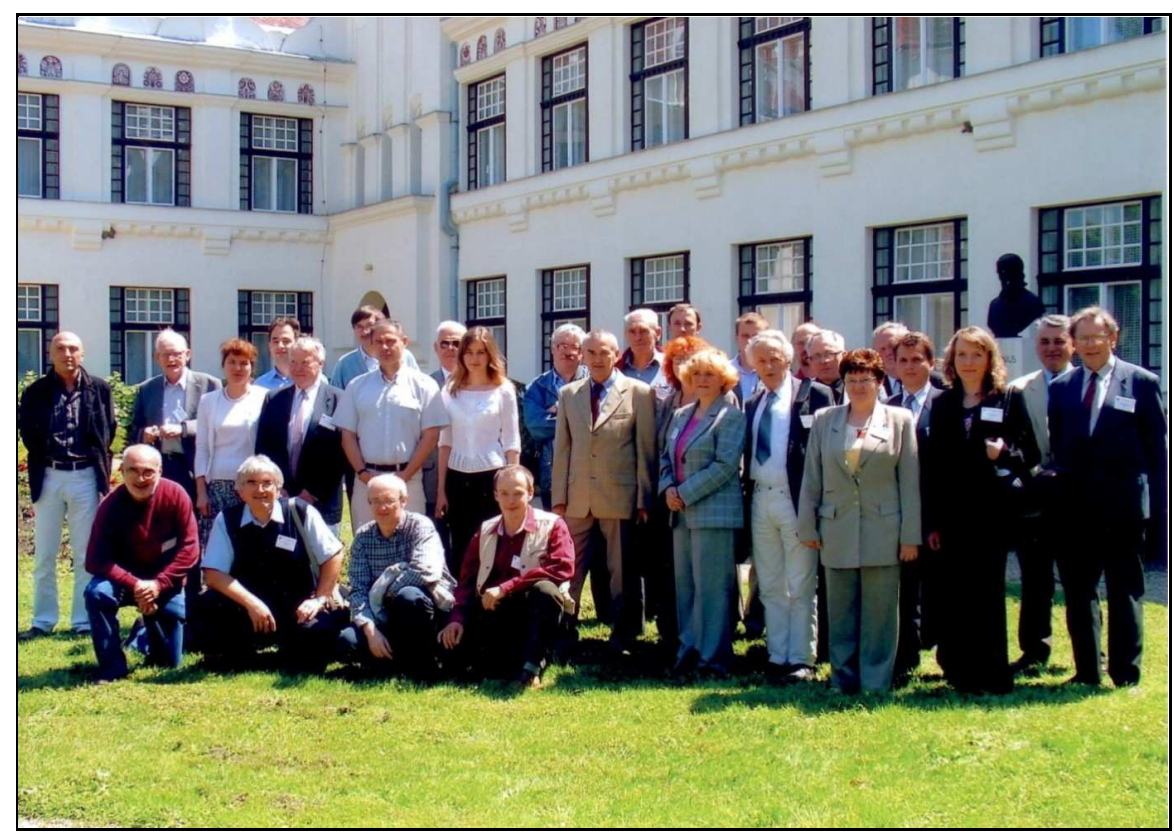

Participants of the Third International Workshop "Constructive Methods for Non-Linear Boundary Value Problems” (7-10 June, 2006, Sárospatak, Hungary)

(C) 2006 Mis KolC UnIVERSITY PRESS 
The scope of the conference covered various topics in the modern theory of boundary value problems in a broad sense, including initial value problems for equations with argument deviations, periodic solutions of functional differential equations, boundary value problems for differential equations with homogeneous non-linearities, the method of lower and upper functions, bifurcation theory, as well as certain aspects of the theory of generalised differential equations, studies of population dynamics, and applications. The workshop was attended by more than 30 researchers from Chile, the Czech Republic, Hungary, Latvia, Slovakia, and the Ukraine, who held 20 and 30-minute lectures.

The Organising Committee of the workshop consisting of G. Bognár, A. Galántai, P. Körtesi, A. Muha Miklósné, A. Samoilenko, A. Rontó, and the author of this note (chairman) gratefully acknowledges the financial support provided by the following funds and institutions:

- Institute of Mathematics, University of Miskolc;

- Faculty of Mechanical Engineering, University of Miskolc;

- Faculty of Economics, University of Miskolc;

- Tudomány Támogatásáért Észak-Magyarországon Alapítvány.

This meeting is a continuation of the two previous workshops held in Miskolc in 2000 and 2006.

We hope that the fruitful tradition of this kind of "compact" international meetings oriented at exchange of ideas of researchers working in closely related fields will continue in the future.

\section{Author's address}

Miklós Rontó:

Institute of Mathematics, University of Miskolc, 3515 MiskolC-EgyetemvÁros, HUNGARY

E-mail address: matronto@gold.uni-miskolc.hu 